In cooperation with the City of Austin, City of Dripping Springs, Barton Springs/Edwards Aquifer Conservation District, Lower Colorado River Authority, Hays County, and Travis County

\title{
Nitrate Concentrations and Potential Sources in the Barton Springs Segment of the Edwards Aquifer and Its Contributing Zone, Central Texas
}

The area contributing recharge to Barton Springs is undergoing rapid growth, accompanied by increased generation of wastewater. This study found that nitrate, a major component of wastewater and a nutrient that can degrade water quality, has increased in Barton Springs and the creeks that provide its recharge.

\section{Key Findings}

Nitrate concentrations in Barton Springs and the five streams that provide most of its recharge were much higher during 2008-10 than before 2008.

Biogenic nitrogen (nitrogen from human or animal waste, or both) is a probable source of nitrate measured in the recharging streams during 2008-10.

Septic systems and land-applied treated wastewater effluent are likely sources contributing nitrate to the recharging streams.

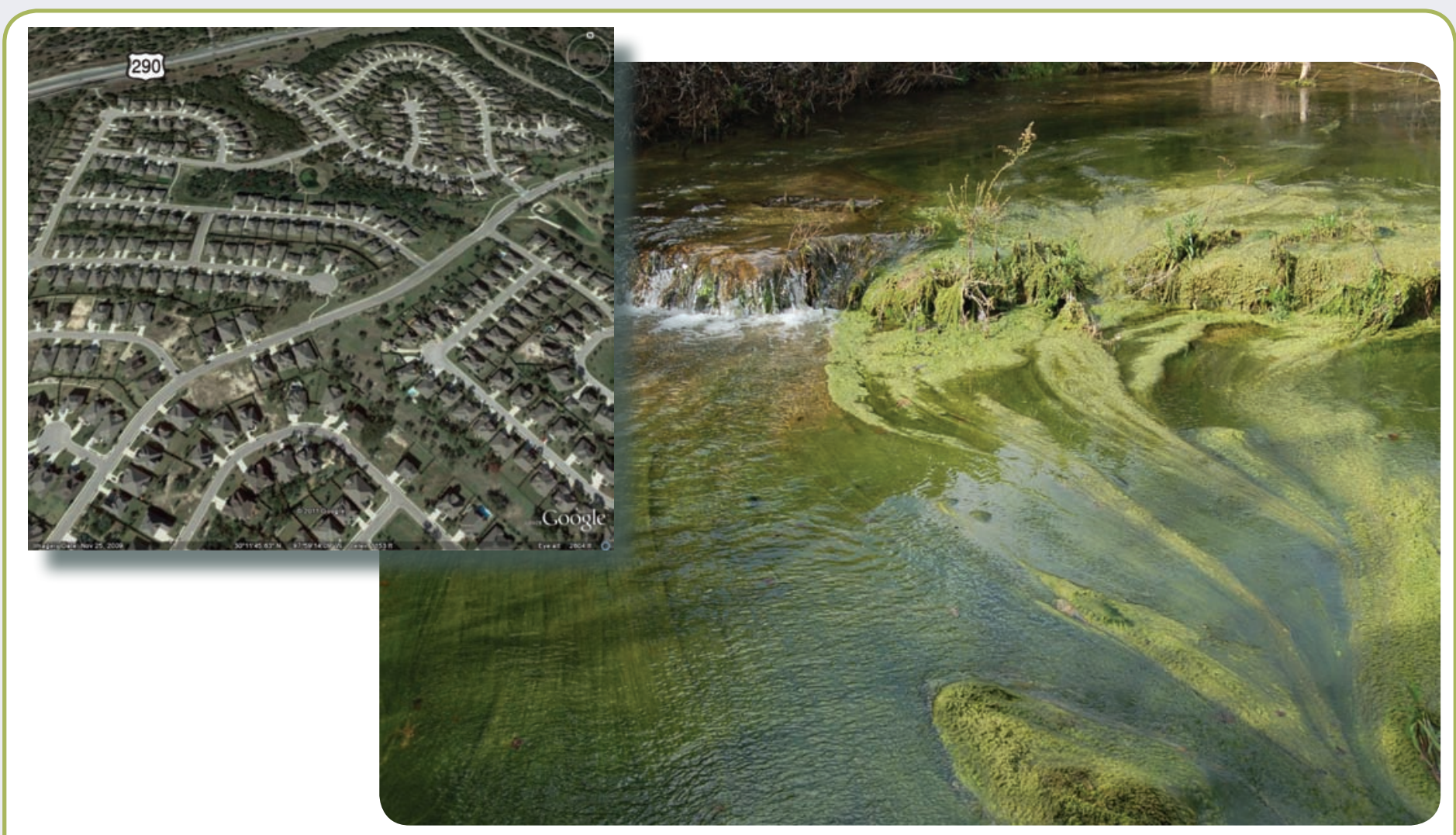

The area providing most of the recharge to Barton Springs has undergone rapid development since 2000 (upper left), with an associated increase in the generation of wastewater. Nitrate and other nutrients in treated wastewater effluent can cause algal blooms as shown here in Bear Creek, one of the five streams providing most of the recharge to Barton Springs, the principal discharge point for the Barton Springs segment of the karstic Edwards aquifer. (Photograph courtesy of Andrew Clamann, City of Austin.) 


\section{Nutrients and Nitrate}

Nutrients are those elements that are important to plant growth and survival and include nitrogen, phosphorus, and potassium. In water, these elements usually take the form of the ions nitrate, phosphate, and potassium. Of these, nitrate is the most soluble and phosphate is the least. Excessive concentrations of nutrients in waterways can cause algal blooms. As the algae die and decompose, dissolved oxygen in the water is consumed, which may cause other organisms, including fish, to die. Nutrients in water have many sources. Natural sources include soils, plant decomposition, animal waste, and rain. Human-related sources include fertilizers, sewage, wastewater, and vehicle exhaust.

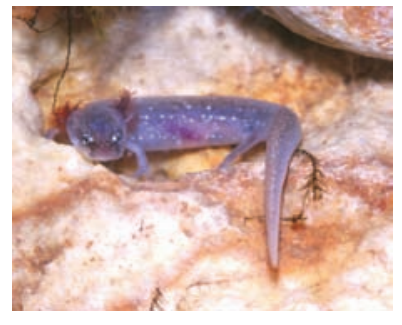

The Barton Springs Salamander (Eurycea sosorum) is one of many aquatic species that requires dissolved oxygen to survive. (Photograph courtesy of Lisa O'Donnell, City of Austin.)

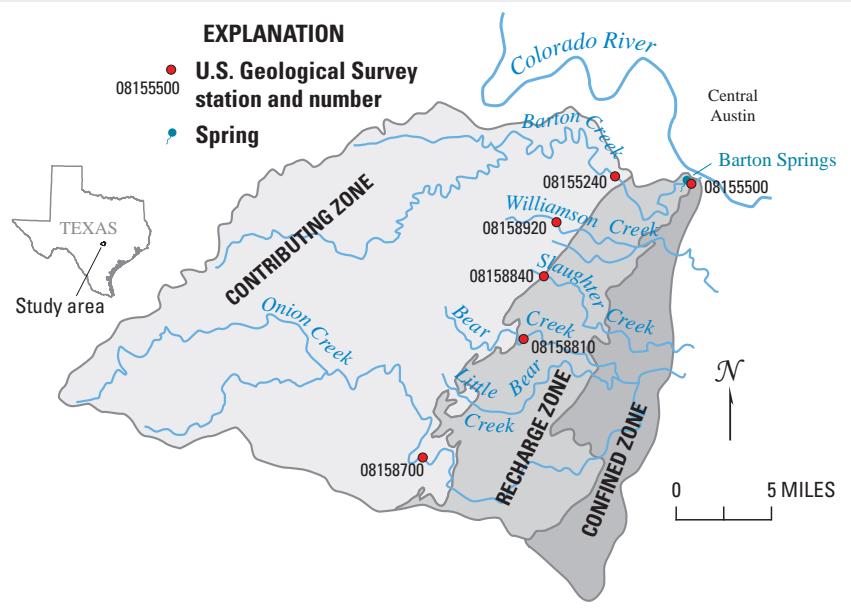

Figure 1. Location of the Barton Springs segment of the Edwards aquifer (recharge and confined zones) and its contributing zone and sampling locations. Samples were collected monthly and in response to storms over 17 months from November 2008 to March 2010.

\section{Nitrate concentrations in Barton Springs and the streams that provide most of its recharge increased beginning around 2005.}

Nitrate was measured in samples collected from five streams recharging the Barton Springs segment of the Edwards aquifer (Barton, Williamson, Slaughter, Bear, and Onion Creeks) near the downstream end of the contributing zone (fig. 1) during November 2008-March 2010. Nitrate concentrations were higher than those in samples collected at the same sites and analyzed by the U.S. Geological Survey (USGS) from the early 1990s until November 2008. Nitrate concentrations in samples collected at station 08158700 Onion Creek near Driftwood, Tex., during 2008-10 were about 6 to 10 times higher than nitrate concentrations for similar streamflows at this station during 1990-2008; nitrate concentrations measured in samples collected at station 08155500 Barton Springs at Austin, Tex., during 2008-10 also were higher, on average, than nitrate concentrations measured during 1990-2008 at this station for similar flow rates (fig. 2). The elevated nitrate concentrations likely resulted in part from the transition from dry to wet conditions in fall 2009, but similar transitions also occurred during 1990-2008, indicating that increased nitrogen loading likely also was a contributing factor.

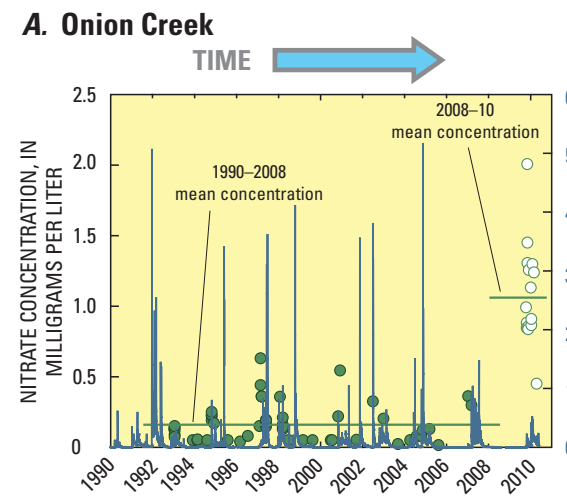

\section{B. Barton Springs}



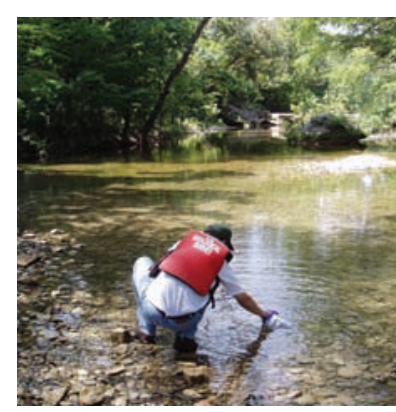

Onion Creck

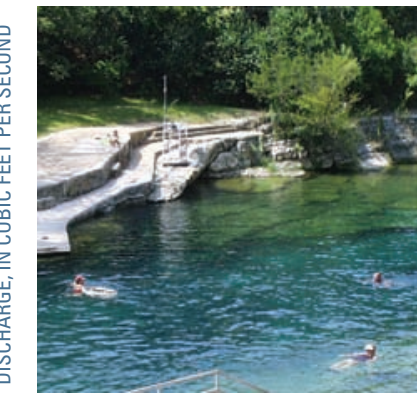

Barton Springs
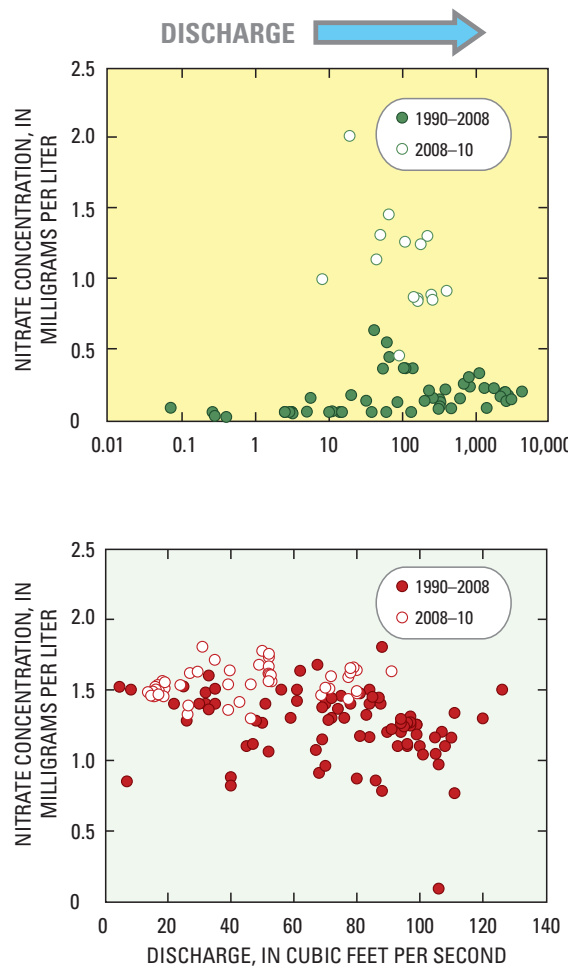

Figure 2. Nitrate concentrations measured in samples collected during 2008-10 $(A)$ at 08158700 Onion Creek at Driftwood, Texas, were about 6 to 10 times higher than nitrate concentrations measured for similar streamflows at the same site during 1990-2008; and $(B)$ at 08155500 Barton Springs at Austin, Texas, also were higher, on average, than nitrate concentrations measured for similar streamflows at the same site during 1990-2008. (Photograph of Barton Springs courtesy of David Johns, City of Austin.) 
Isotopes of nitrogen and oxygen in nitrate were measured in water samples collected from Barton Springs at station 08155500 and the five streams recharging the aquifer during November 2008-March 2010. During November 2008-September 2009 (the dry period), only Barton Creek flowed continuously. Nitrate in water samples from station 08155240 Barton Creek at Lost Creek Blvd. near Austin, Tex., during the dry period had an isotopic signature very similar to that for wastewater effluent, indicating a contribution of biogenic nitrate that has undergone some denitrification (fig. 3). The isotopic signature of nitrate in samples collected from Barton Springs during the dry period indicates a soil source of nitrate with a potential contribution from biogenic sources.

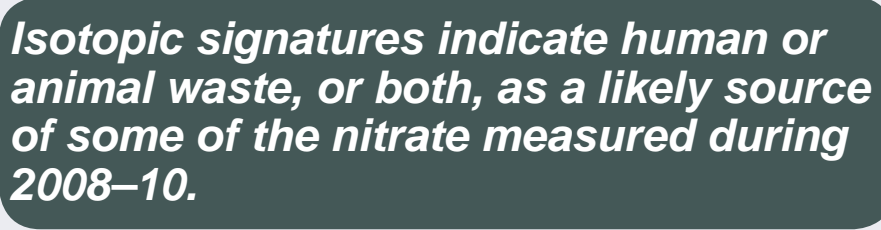

Isotopic Ratios of Nitrate as a Tracer of Sources

Isotopes of a particular element have the same number of protons in the atomic nucleus but different numbers of neutrons, resulting in different atomic masses. Stable isotopes of nitrogen (nitrogen-14 $\left[{ }^{14} \mathrm{~N}\right]$ and nitrogen-15 $\left.\left[{ }^{15} \mathrm{~N}\right]\right)$ and the principal stable isotopes of oxygen (oxygen-16 $\left[{ }^{16} \mathrm{O}\right]$ and oxygen-18 $\left[{ }^{18} \mathrm{O}\right]$ ) are incorporated into compounds in different proportions depending on the nature of the reactions that produce the compounds. As a result, different sources or reservoirs of nitrate have characteristic isotopic "signatures" $\left({ }^{15} \mathrm{~N}\right.$ relative to ${ }^{14} \mathrm{~N}$, expressed as $\delta^{15} \mathrm{~N}$, and ${ }^{18} \mathrm{O}$ relative to ${ }^{16} \mathrm{O}$, expressed as $\delta^{18} \mathrm{O}$ ). The ratios of the isotopes of nitrogen and oxygen in nitrate often are useful for determining sources of nitrate in groundwater and surface water. Isotopic ratios are expressed as the ratio of the heavier isotope to the lighter isotope relative to a standard (nitrogen in air for $\delta^{15} \mathrm{~N}$ and oxygen in standard mean ocean water (SMOW) for $\delta^{18} \mathrm{O}$ ), in parts per thousand (per mil).

During mid-September 2009 to March 2010 (the wet period), flow was continuous in all five streams, and the isotopic signatures of the nitrate in recharging creeks and in Barton Springs discharge were relatively similar. The isotopic composition of nitrate in water samples from the five recharging creeks indicates a mix of nitrate from soils and biogenic sources at Onion Creek, with a progressively increasing component of biogenic nitrate in the samples collected from USGS stations on Barton, Bear, Slaughter, and Williamson Creeks.

At Barton Springs, the values of $\delta^{15} \mathrm{~N}$ during the wet period increased progressively, indicating an increasing contribution of biogenic nitrate. This is consistent with an increased amount of recharge from the creeks, which flowed continuously throughout the wet period.

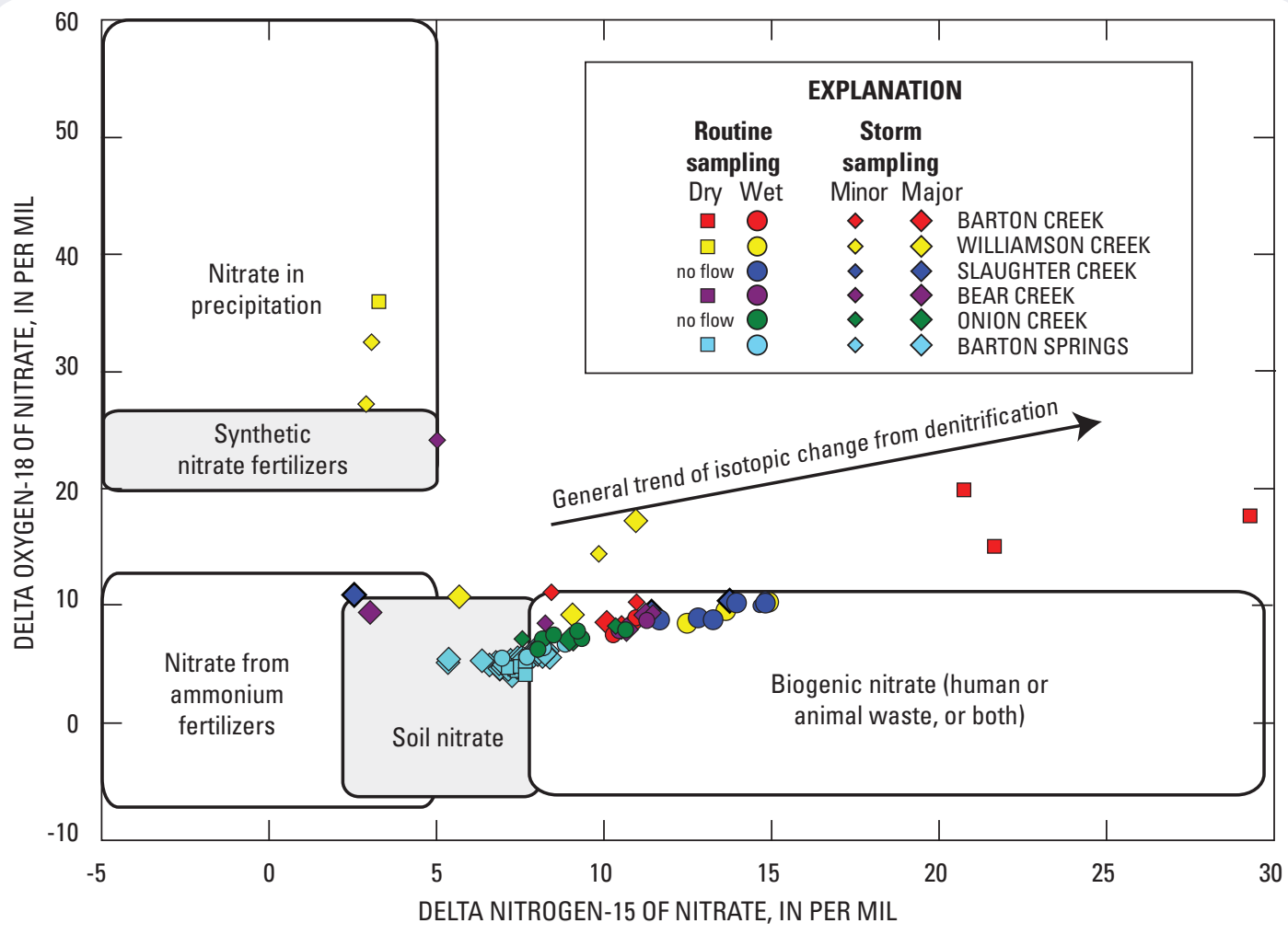

Figure 3. The isotopic composition of the nitrate in water samples from creeks recharging the Barton Springs segment of the Edwards aquifer and from Barton Springs during the dry period (November 2008September 2009) and the wet period (September 2009-March 2010). (Isotopic fields modified from Silva and others, 2002.) 


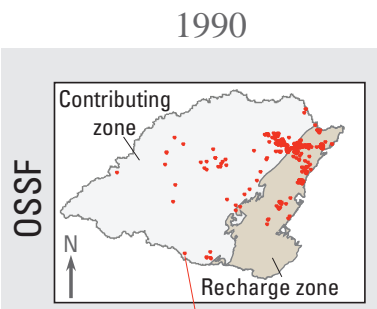

Onsite sewage facility
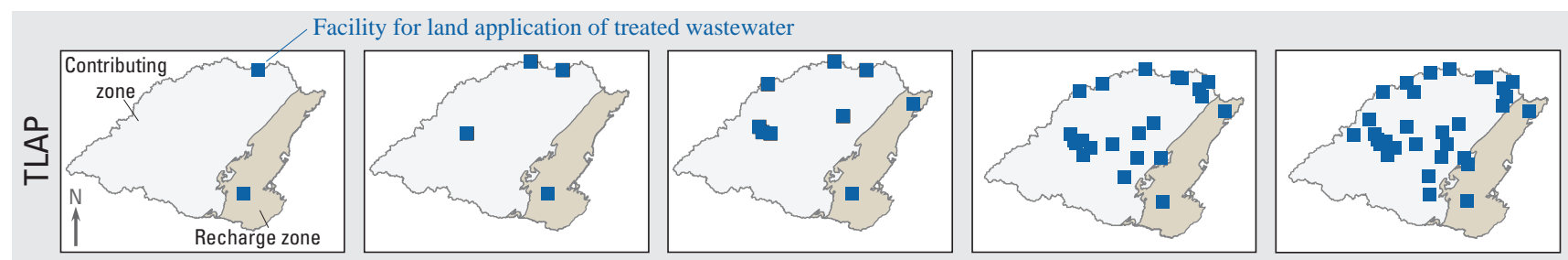

Figure 4. Permits for on-site sewage facilities (OSSFs) (septic systems) and land application of treated wastewater (Texas Land Application Permits [TLAPs]) on the Barton Springs contributing and recharge zones have increased greatly since 1990.

Rapid development over the contributing zone since 2000 has been accompanied by an increase in the generation of wastewater. Currently (November 2010), septic systems (also referred to as on-site sewage facilities, or OSSFs) and land application of treated wastewater effluent (Texas Land Application Permits, or TLAPs) are the two methods used for disposal of treated wastewater effluent in the Barton Springs contributing zone, and are likely sources of biogenic nitrate. The number of OSSFs and TLAPs increased greatly from 2000 to 2010 (fig. 4). Other sources of biogenic nitrate (livestock and domesticated dogs and cats) are unlikely to be the source of increased nitrate in any of the watersheds in the contributing zone.

Septic systems. There were 6,217 OSSFs permitted during 200110 , about 4.5 times the total number permitted prior to 2001 . The most permits were issued in 2001. Although the most permits were issued for properties in the Barton and Onion Creek watersheds, the greatest density of OFFSs (systems per acre) is in the Bear Creek watershed.

Land application of treated wastewater. Currently (November 2010), the permitted volume of irrigated flow is 3,300,000 gallons per day. About 95 percent of that volume was permitted during 2005-10. The volume of new irrigation permitted annually peaked in 2005. Both the greatest irrigation volume and rate (volume per day per acre) are in the Barton Creek watershed. There are no irrigation facilities in the Williamson Creek watershed, and no new facilities have been permitted in the Slaughter Creek watershed since 1997.

\section{What Does the Future Hold?}

Population over the Barton Springs contributing and recharge zones is projected to double between 2010 and 2035, with most of this growth projected to occur in the Barton and Onion Creek watersheds (Capital Area Metropolitan Planning Organization, 2010). Projected population increases are prompting plans for direct discharge of treated wastewater into contributing zone streams. Currently (November 2010) there are no direct discharges of treated wastewater into the recharging creeks, but one wastewater discharge permit has been issued for the Bear Creek watershed. Small streams in Central Texas receiving wastewater effluent have been demonstrated to have elevated nutrient concentrations and to be eutrophic (Mabe, 2007).

Publishing support provided by Lafayette Publishing Service Center
Increases in nitrate concentrations coincide with rapid increases in number of septic systems (OSSFs) and volume of land application of treated wastewater (TLAPs), sources of biogenic nitrogen, in the Barton Springs contributing zone.

\section{References}

Capital Area Metropolitan Planning Organization, 2005, 2005 to 2035 Demographics: accessed on December 12, 2010, at http://www. campotexas.org/Word/2035\%20Final\%20TSZ.zip.

Mabe, J.A., 2007, Nutrient and biological conditions of selected small streams in the Edwards Plateau, Central Texas, 2005-06, and implications for development of nutrient criteria: U.S. Geological Survey Scientific Investigations Report 2007-5195, 46 p.

Silva, S.R., Ging, P.B., Lee, R.W., Ebbert, J.C., Tesoriero, A.J., and Inkpen, E.L., 2006, Forensic applications of nitrogen and oxygen isotopes in tracing nitrate sources in urban environments: Environmental Forensics, v. 3, no. 2, p. 125-130.

\section{This fact sheet is based on the following report:}

Mahler, B.J., Musgrove, MaryLynn, Herrington, Chris, and Sample, T.L., 2011, Recent (2008-10) concentrations and isotopic compositions of nitrate and concentrations of wastewater compounds in the Barton Springs zone, south-central Texas, and their potential relation to urban development in the contributing zone: U.S. Geological Survey Scientific Investigations Report 2011-5018, 39 p.

-Barbara J. Mahler, ${ }^{1}$ MaryLynn Musgrove, ${ }^{1}$ and Chris Herrington ${ }^{2}$

${ }^{1}$ U.S. Geological Survey.

${ }^{2}$ City of Austin.

Any use of trade, product, or firm names is for descriptive purposes only and does not imply endorsement by the U.S. Government.

\section{For additional information, contact}

Director

USGS Texas Water Science Center

http://tx.usgs.gov/

gs-w-txpublic-info@usgs.gov 